\title{
PENGENTASAN PENGANGGURAN BAGI PEMUDA DI DESA CIGUDEG MELALUI KEGIATAN BUDIDAYA IKAN LELE
}

\section{ALLEVIATION OF YOUTH UNEMPLOYMENT IN CIGUDEG VILLAGE THROUGH CATFISH BREEDING ACTIVITIES}

\author{
${ }^{1)}$ Yayat Sujatna, ${ }^{2)}$ Imal Istimal \\ ${ }^{1)}$ Program Studi Manajemen, ${ }^{2)}$ Program Studi Manajemen \\ STIE Ahmad Dahlan Jakarta \\ Jl. Ciputat Raya No. 77, Cireundeu, Tangerang Selatan, Banten 15419 \\ email: yayatsujatna@gmail.com
}

\begin{abstract}
ABSTRAK
Salah satu daerah dengan tingkat kemiskinan dan pengangguran tertinggi di Provinsi Jawa Barat adalah Kabupaten Bogor. Upaya untuk mengurangi kemiskinan dan pengangguran tersebut diantaranya adalah melalui kewirausahaan. Kegiatan pengabdian masyarakat ini dilakukan sebagai salah satu upaya mengurangi pengangguran tersebut. Adapun tujuan pengabdian masyarakat ini adalah: (1) meningkatnya pemahaman mitra tentang kewirausahaan; (2) terbentuknya usaha budi daya lele bagi khalayak sasaran (mitra); (3) mitra mampu mengelola usaha budi daya lele; dan (4) meningkatkan pendapatan mitra. Metode pelaksanaan kegiatan dilaksanakan melalui metode ceramah (pemberian motivasi) dan praktik lapangan, yaitu budidaya ikan lele. Metode ceramah dilakukan melalui pemberian materi selama satu kali dua jam. Materi diberikan dengan tujuan memberikan pembahaman tentang arti penting berwirausaha. Hasil dari kegiatan ini adalah adanya peningkatan pemahaman dan motivasi mitra tentang kewirusahaan. Pada level implementasi (praktek budidaya ikan lele), budidaya dilakukan di kolam terpal dengan bibit sebanyak 7.000 ekor dengan pemberian full pelet (paka ikan lele). Panen periode pertama menghasilkan $20 \mathrm{~kg}$ dan mengalami kerugian sebesar Rp. 750.000. Kendalanya adalah manajemen air dan penggunaan kolam terpal. Budidaya periode kedua dilakukan di kolam tanah dengan penebaran bibit sebanyak 5.000 dengan pakan pelet dan pakan alternatif. Panen pada periode ini sebanyak $300 \mathrm{~kg}$ dengan keuntungan sebedsar Rp. 850.000 .
\end{abstract}

Kata Kunci: Pengangguran, Kewirausahaan, Pemuda, Pelatihan, Budidaya Ikan Lele

\section{ABSTRACT}

One of the regions with the highest poverty and unemployment rate in West Java Province is Bogor Regency. Efforts to reduce poverty and unemployment are among others through entrepreneurship. Community service activities are conducted to reduce unemployment. The purpose of community service is: (1) increasing understanding of partners about entrepreneurship; (2) the formation of catfish farming business for the target audience (partners); (3) partners able to manage catfish farming business; and (4) increase partner revenue. Method of implementation of activities carried out through lecture method (giving motivation) and field practice, namely catfish farming. The lecture method is done through the giving of material for one time two hours. The material is given for the purpose of providing an understanding of the importance of entrepreneurship. The result of this activity is an increase in understanding and motivation 
Yayat Sujatna, Imal Istimal

Pengentasan Pengangguran Bagi Pemuda Di Desa Cigudeg Melalui Kegiatan Budidaya Ikan Lele

of partners about entrepreneurship. At the implementation level (the practice of catfish farming), the cultivation is done in a tarpaulin pool with 7,000 seedlings with full pellet (catfish). The first harvest period produced $20 \mathrm{~kg}$ and suffered a loss of Rp. 750,000. The problem is water management and use of the tarpaulin pool. The second cultivation period was conducted in a ground pool with 5,000 seedlings with alternative feed and pellet feed. Harvest in this period as much as $300 \mathrm{~kg}$ with a profit of Rp. 850,000

Keywords: Unemployment, Entrepreneurship, Youth, Training, Catfish Farming

Submitted: 15 Maret 2018 Revision: 18 Mei $2018 \quad$ Accepted : 10 Juli 2018

\section{PENDAHULUAN}

Isu pengangguran dan kemiskinan sering menjadi masalah utama yang dihadapi oleh negara berkembang seperti Indonesia. Per Maret 2016 misalnya BPS mencatat kemiskinan di Indonesia mencapai 28,01 juta jiwa atau sebesar 10,86 persen dari total jumlah penduduk Indonesia dengan indeks kedalaman sebesar 2,74. Berdasarkan profil kemiskinan BPS, walaupun dari sisi jumlah kemiskinan di perdesaan menurun, namun secara persentase penduduk miskin meningkat. Sementara angka pengangguran per Pebruari 2016 mencapai 7,02 juta orang atau 5,5 persen. Meskipun jumlah pengangguran tersebut menurun bila dibandingkan dengan Februari 2015, yang mencapai 7,45 juta orang $(5,81$ persen $)$ namun penurunannya tidak signifikan.

Salah satu karakteristik Indonesia adalah bahwa angka pengangguran cukup tinggi yang dihadapi oleh tenaga kerja muda usia 15 sampai 24 tahun, jauh lebih tinggi dari angka rata-rata pengangguran secara nasional. Mahasiswa yang baru lulus dari universitas dan siswa sekolah kejuruan dan menengah mengalami kesulitan menemukan pekerjaan di pasar kerja nasional. Hampir setengah dari jumlah total tenaga kerja di Indonesia hanya memiliki ijazah sekolah dasar saja. Semakin tinggi pendidikannya semakin rendah partisipasinya dalam kekuatan tenaga kerja Indonesia. Meskipun demikian dalam beberapa tahun terakhir terlihat adanya perubahan tren: pangsa pemegang ijazah pendidikan tinggi semakin besar, dan pangsa pemegang ijazah pendidikan dasar semakin berkurang (sumber: indonesiainvestmen.com).

Tingginya tingkat kemiskinan di Indonesia sebagai representasi dari tingginya angka kemiskinan dan pengangguran di daerah-daerah. Salah satu daerah dengan tingkat kemiskinan dengan pengangguran yang cukup tinggi adalah Kabupaten BogorJawa Barat, bahkan tertinggi di Jawa Barat. Tahun 2013, BPS Kabupaten Bogor merilis jumlah pengangguran di Kabupaten Bogor mencapai 230 ribu orang, tertinggi di Jawa Barat. Padahal Kabupaten Bogor merupakan daerah industri padat karya. Tingginya angka pengangguran ini lebih disebabkan oleh rendahnya pendidikan masyarakat di Kabupeten Bogor, sehingga tidak terserap oleh perusahaan-perusahaan yang umumnya mensyaratkan tingkat pendidikan yang tinggi.

Besarnya tingkat pengangguran terbuka mempunyai implikasi sosial yang sangat rawan dan luas terhadap kehidupan masyarakat, karena mereka tidak bekerja dan tidak memiliki pendapatan. Semakin tinggi

JPPM ISSN: 2549 - 8347 (Online)

ISSN: 2579 - 9126 (Print)

Vol. 2 No. 2 September 2018 
Yayat Sujatna, Imal Istimal Pengentasan Pengangguran Bagi Pemuda Di Desa Cigudeg Melalui Kegiatan Budidaya Ikan Lele

tingkat pengangguran terbuka semakin tinggi tingkat kerawanan sosial, bahkan dapat menimbulkan tingkat kriminalitas menjadi semakin tinggi. Sebaliknya, jika tingkat pengangguran terbuka dapat ditekan dan diperkecil, maka kerawanan sosial akan berkurang dan bahkan meningkatkan kesadaran sosial yang tinggi sebagai akibat dari tingkat kemakmuran yang semakin merata (Dimyati dan Sari, 2016).

Upaya mengetaskan kemiskinan dan pengangguran dapat dilakukan setidaknya dengan tiga pendekatan, yaitu penciptaaan lapangan kerja yang dapat menyerap tenaga kerja non skill, pembekalan keterampilan untuk memenuhi persyaratan industri, atau dengan pendekatan kewirausahaan. Pendekatan yang ketiga yang memungkinkan dapat dilakukan dan lebih pasti serta tidak perlu membutuhkan waktu yang lama.

Menurut Konadi dan Irawan (2012), kewirausahaan dapat mengatasi pengangguran dan kesempatan kerja yang semakin sempit. Sehingga kewirausahaan dapat menjadi satu alternatif yang dapat dikedepankan untuk mengatasi masalah tersebut. Karena menurut Burhanudin (2010) wirausaha bertindak sebagai agen perubahan, membawa ide-ide baru untuk pasar dan merangsang pertumbuhan melalui proses persaingan perusahaan.

Atas dasar uraian di atas, pengabdian masyarakat ini dilakukan terhadap pemuda (belum bekerja) di Kp. Cigudeg RT/RW. 03/11Ds/Kec. Ciuncal, Kab. Bogor-Jawa Barat. Sebagaimana diketahui, pemuda di daerah ini masih banyak yang belum memiliki pekerjaan yang pasti. Penyebabnya adalah selain tingkat pendidikan formal yang rendah, keterampilan yang dimiliki juga masih rendah.

Lokasi pengabdian merupakan daerah perbatasan antara Kabupaten Rangkas Bitung dengan Kabupaten Bogor serta Tangerang/Kota Tangerang Selatan. Sebagai daerah perbatasan, Desa Cigudeg merupakan
Desa yang memiliki akses jauh dari pusat perkotaan. Meskipun demikian, daerah ini memiliki potensi ekonomi untuk dikembangkan, terutama pada bidang pertanian atau perikanan. Karena memiliki lahan yang belum dimanfaatkan secara optimal serta sumber air yang bagus.

Namun besarnya potensi ini tidak bisa sepenuhnya dimanfaatkan oleh masyarakat setempat dikarenakan berbagai alasan, seperti rendahnya keterampilan yang dimiliki serta tingkat kemauan yang rendah, sebagai akibat dari tingkat pendidikan yang rendah. Berdasarkan data dari Pemerintah Kabupaten Bogor, angka putus sekolah tertinggi berada di Desa Cigudeg pada tahun 2015. Tidak hanya itu, Pemerintah Kabupaten Bogor juga mencatat bahwa Desa Cigudeg merupakan Desa dengan jumlah penduduk yang tidak memiliki jamban dan listrik tertinggi. Tidak heran apabila masih banyak warga Cigudeg yang masih menganggur atau tidak memiliki pekerjaan tetap.

Meskipun daerah Ciuncal merupakan daerah yang memiliki potensi pertanian yang baik, namun mayoritas masyarakatnya lebih memilih profesi lain dalam bekerja seperti menjadi buruh/karyawan, berdagang, dan lain sebagainya dibandingkan dengan memilih untuk menjadi petani atau memanfaatkan lahan pertanian. Padahal bidang ini sangat menjanjikan di daerah Ciuncal karena selain lahan yang subur dan luas, juga memiliki akses atau infrastruktur yang baik. Sehingga proses pertanian sampai dengan pemasaran akan mudah dilakukan. Apalagi Ciuncal merupakan daerah yang tidak jauh dari kotakota besar seperti Kota Bogor, Tangerang, atau Jakarta.

Diantara potensi yang dapat dikembangkan di desa atau kampung Ciuncal ini adalah perikanan. Tidak hanya tanah yang subur yang dimiliki oleh kampung Ciuncal ini, namun juga memiliki sumber air yang melimpah. Karena tidak hanya ladang, di 
Yayat Sujatna, Imal Istimal

Pengentasan Pengangguran Bagi Pemuda Di Desa Cigudeg Melalui Kegiatan Budidaya Ikan Lele

kampung ini juga terdapat daerah persawahan. Keberadaan Situ Cigudeg yang berada di kampung Ciuncal merupakan salah satu konfirmasi bahwa daerah ini memiliki sumber air yang baik. Namun potensi ini tidak banyak dimanfaatkan oleh masyarakat seperti untuk budidaya ikan. Alasan utamanya adalah rendahnya kapasitas masyarakat dalam budidaya ikan. Sehingga ketika gagal langsung menyerah. Keberadaan Situ Cigudeg hanya dimanfaatkan oleh masyarakat untuk memancing. Padahal tingginya sumber air dapat dimanfaatkan untuk kepentingan atau kegiatan yang memiliki nilai ekonomi yang tinggi, seperti budidaya ikan.

\section{METODE KEGIATAN}

Pelaksanaan kegiatan pengabdian masyarakat dilaksanakan melalui metode ceramah (pemberian motivasi), dan praktik lapangan (budidaya ikan lele). Metode ceramah (materi kelas) dilakukan dengan memberikan materi melalui presentasi kepada mitra mengenai kewirausahaan, dan budidaya lele. Diharapkan mitra selain mengetahui tentang aspek-aspek kewirausahaan, peserta juga termotivasi untuk memulai usaha. Materi yang diberikan dalam metode ini adalah pengertian wirausaha, tujuan dan keuntungan beriwirausaha, langkah-langkah berwirausaha, hambatan-hambatan dalam berwirausaha dan solusi dalam menghadapi habatan-hambatan tersebut.

Dalam tahap ini juga peserta diberikan materi (pemahaman) tentang usaha budidaya ikan lele. Materi yang diberikan mulai dari keuntungan dan kelemahan dalam berbisnis ikan lele, analisis usaha, persiapan, pengoperasian, dan bagaimana menangani pasca panen baik pengolahan maupun pemasaran.

Pada tahap implementasi atau praktek budidaya ikan lele, berpedoman pada (Muhammad dan Andryanto, 2013) mulai dari persiapan sarana dan prasarana sampai dengan produksi dan pemasaran.

Selain praktek lapangan, pada kegiatan ini juga dilakukan tahap evaluasi. Jika usaha ini berhasil sesuai target, yaitu berhasil panen dengan tingkat kegagalan (kematian) 10\%, maka dilakukan budidaya untuk tahap atau periode selanjutnya secara terus menerus sampai dengan mendapatkan profit pada tingkat yang diinginkan. Namun jika gagal (usaha tidak menguntungkan), maka dilakukan evaluasi. Pada tahap evaluasi dilakukan identifikasi masalah-masalah yang dihadapi selama proses budidaya. Jika sudah teridentifikasi, selanjutnya dicarikan solusi dan dilanjutkan dengan budidaya selanjutnya.

Bagan alur metode pelaksanaan kegiatan sebagaimana tergambar dalam gambar di bawah ini.

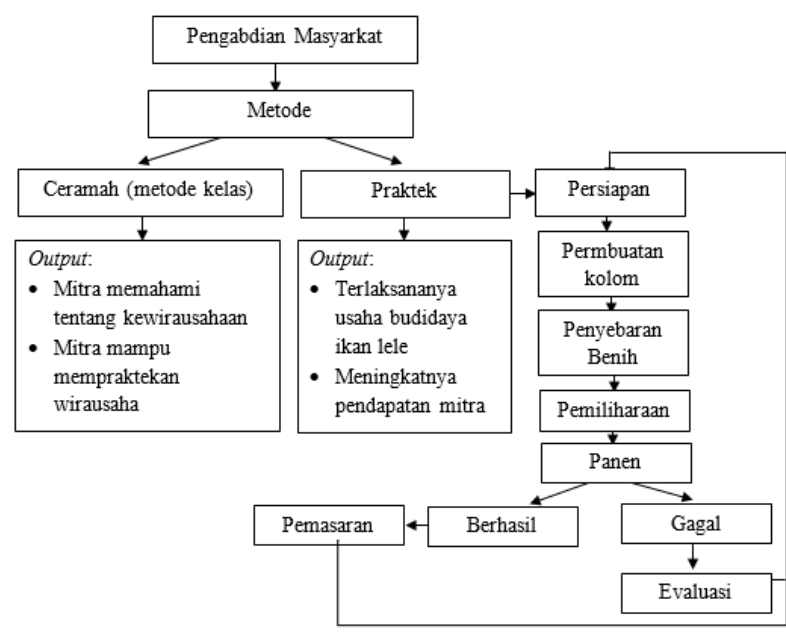

Gambar 2. Metode dan Pelaksanaan Pengabdian Masyarakat

\section{HASIL DAN PEMBAHASAN}

Hasil dari kegiatan pengabdian ini adalah:

1. Meningkatnya pemahaman mitra terhadap kegiatan berwirausaha. 
Yayat Sujatna, Imal Istimal Pengentasan Pengangguran Bagi Pemuda Di Desa Cigudeg Melalui Kegiatan Budidaya Ikan Lele

Rendahnya minat masyarakat, dalam hal ini adalah mitra (khalayak sasaran), terhadap kewirausahaan dapat diakibatkan dari rendahnya pemahaman masyarakat tentang kewirausahan serta. Selain itu, motivasi masyarakat dalam berwirausaha juga rendah, sehingga sulit untuk memiliki jiwa wirusaha. Untuk memenuhi kekurangan khalayak tersebut, dalam pengabdian ini diberikan motivasi dan materi kewirausahaan kepada mitra (khalayak sasaran). Materi dan motivaasi ini diberikan selama empat jam dalam satu hari. Tujuan diberikannya materi ini adalah selain untuk menambah motivasi mitra, juga untuk membekali mitra dalam berwirausaha. Sebagaimana tujuan dari kegiatan pengabdian ini, yaitu:
a. Memberikan
pemahaman tentang pentingnya berwirausaha untuk kepentingan pribadi, masyarakat sekitar, bahkan bangsa dan negara;

b. Memberikan pengetahuan tentang bagaimana menggali potensi di daerah mitra agar dijadikan peluang berwirausaha;

c. Memberikan pelatihan dan pendam-pingan budidaya lele dari awal sampai dengan akhir (panen) dan pasca panen, termasuk kegiatan pemasaran dana menajemen keuangan sederhana;

Adapun materi kewirausahaan yang diberikan pada kegiatan pengabdian masyarakat ini adalah berdasarkan modul dari Kemendikbud (2013) sebagai berikut: (1) pengertian wirausaha; (2) pengusaha, wirausaha, dan penemu; (3) wirausahawan dan manajer; (4) kualitas dan karakteristik wirausahawan; (5) wirausaha dilahirkan, dicetak, atau lingkungan; (6) manfaat mempelajari kewirausahaan. Tujuan ceramah ini adalah: (1) peserta kegiatan memahami pengertian kewirausahawan; (2) peserta mampu membedakan, pengusaha, wirausahawan, dan penemu, serta contohnya; wirausahawan dan manajer, serta contohnya; (4) peserta mampu menjelaskan kualitas dan karakteristik wirausahawan; (5) peserta mampi menjelaskan wirausahawan dilahirkan, dicetak, atau lingkungan; dan (6) peserta mampu menjelaskan manfaat mempelajari kewirausahaan.

Hasil dari pemberian materi ini adalah mitra terbuka wawasannya tentang kewirausahaan dan termotivasi untuk melalukan wirausaha sesuai dengan potensi yang ada di daerah tempat tinggal mereka. Indikator dari hal ini, terlihat dari adanya kemauan yang kuat dari mitra untuk mempraktikan secara langsung wirausaha budidaya ikan lele.

\section{Implementasi Budidaya Ikan Lele}

Kegiatan ini merupakan inti dari kegiatan pengabdian masyarakat, sekaligus sebagai tidaklanjut dari pemberian materi dan motivasi berwirausaha sebelumnya. Pemberian materi tentu saja tidak akan cukup jika tidak dibarengi atau diikuti dengan praktik lapangan. Khalayak sasaran diberikan waktu sepenuhnya untuk melakukan praktik lapangan (budidaya lele). Praktek budidaya ikan lele ini diambil sebagai praktik kewirausahaan dengan beberapa pertimbangan, antara lain:

a. Daerah mitra (Kp. Cigudeg) memiliki sumber air yang cukup untuk budidaya ikan;

b. Ikan lele dipilih karena lebih mudah dibudidaya dengan air yang tidak perlu banyak, dan tingkat atau sirkulasi (waktu) panen yang relatif singkat dibandingkan dengan budidaya ikan tawar lainnya. Serta perawatan yang cukup mudah;

c. Ikan lele merupakan jenis ikan yang mudah dipelihara. Kondisi air seperti apapun dapat dijadikan media pembesaran ikan lele; 
Yayat Sujatna, Imal Istimal

Pengentasan Pengangguran Bagi Pemuda Di Desa Cigudeg Melalui Kegiatan Budidaya Ikan Lele

d. Tidak ada ketentuan khusus untuk lokasi pemeliharaan ikan lele. Karena ikan lele dapat hidup di segala tempat, termasuk yang berada di ketinggian $1000 \mathrm{mdpl}$. Hal yang harus diperhatikan benar-benar selain suhu, yaitu $\mathrm{pH}$. Kondisi tempat harus berada dalam kisaran $\mathrm{pH}$ 7-8.

e. Pelaksana pengabdian memiliki kompetensi dan pengalaman dalam budidaya ikan lele. Hal ini menjadi modal bagi keberhasilan praktik kewirausahaan.

f. Selain itu, di daerah lain di luar Cigudeg banyak yang melakukan budidaya ikan lele termasuk pembibitan. Sehingga dapat memudahkan untuk mendapatkan bibit dan pemasaran;

Praktik kewirasuahaan ini dilakukan sepanjang dilakukannya pengabdian dan akan terus dilakukan pembinaan sampai mitra benar-benar mendapatkan hasil atau manfaat dari pengabdian ini. Dalam rentang pengabdian ini, praktik kewirausahaan telah dilakukan sebanyak dua periode. Proses pengerjaan atau budidaya ini mengacu pada tabel/jadwal yang telah dibuat.

\section{Periode pertama}

Periode ini merupakan periode awal sekaligus percobaan (eksperimen) untuk mengetahui tingkat keberhasilan. Pada periode ini tahapan-tahapan yang dilakukan dalam praktik budidaya ikan lele adalah persiapan kolam terpal, persiapan benih, pemeliharaan, dan panen.

Pada periode ini praktik budidaya ikan lele dilakukan di kolam terpal. Kolam terpal dibuat luas 2 × 3 meter dengan rangka bambu. Setelah kolam sudah siap dan diberi air dan diberi obat, tahap selanjutnya adalah menyiapkan bibit atau membeli benih ikan lele. Benih ikan lele untuk pembesaran berbeda dengan pembenihan. Benih ikan lele untuk pembesaran ini dipilih dengan kisaran ukuran antara 5-7 cm.

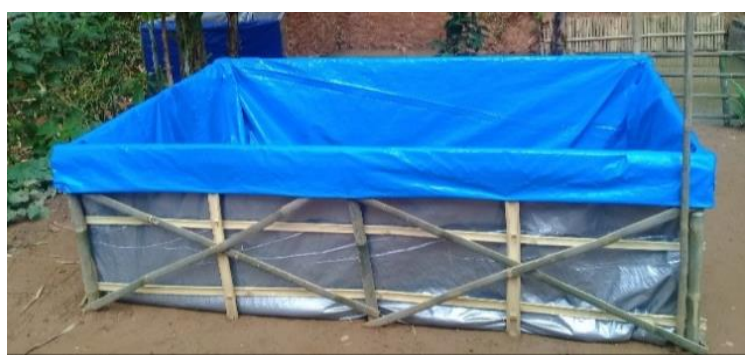

Gambar 3. Pembuatan Kolam Terpal

Dilanjutkan dengan pemeliharaan. Pemeliharaan ini meliputi pemberian pakan dan obat serta pengurasan kolam ikan. Makanan ikan yang diberikan adalah pellet (full pellet) yang telah dicampur obat atau probiotik sehari dua kali, pagi dan sore hari. Sementara pengurasan kolam atau penggantian air dilakukan dua minggu sekali atau sesuai dengan kebutuhan.

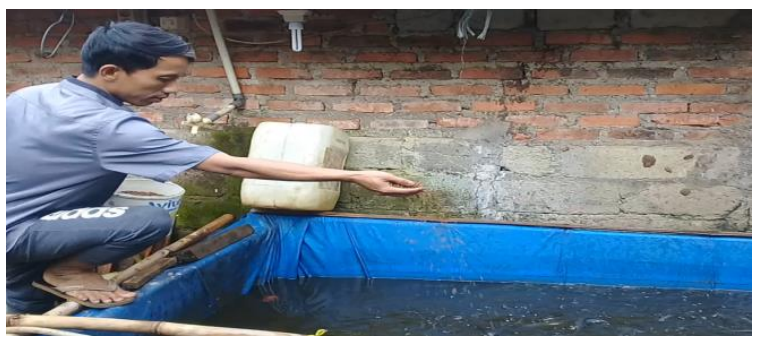

Gambar 4. Pemeliharaan di Kolam Terpal

Setelah kurang lebih tiga bulan ikan lele siap dipanen. Panen periode pertama menghasilkan $20 \mathrm{~kg}$ ikan lele. Pada panen periode ini mengalami kerugian sebesar $\mathrm{Rp}$ 750.000; Kerugian ini lebih diakibatkan pada manajemen air yang rendah sehingga pertumbuhan ikan lambat dan pemilihan penggunaan kolam terpal sebagai tempat budidaya ikan lele.

\section{Periode kedua}


Yayat Sujatna, Imal Istimal

Pengentasan Pengangguran Bagi Pemuda Di Desa Cigudeg Melalui Kegiatan Budidaya Ikan Lele

Belajar dari penyebab kegagalan pada periode pertama dengan menggunakan kolam terpal, pada periode kedua dilanjutkan dengan menggunakan kolam langsung di tanah. Selain untuk menggantikan kolam terpal yang gagal, kolam tanah juga dipilih karena lebih efisien dibandingkan dengan kolam terpal, tidak perlu menyewa atau membeli kolam, karena memanfaatkan kolam-kolam yang telah ada.

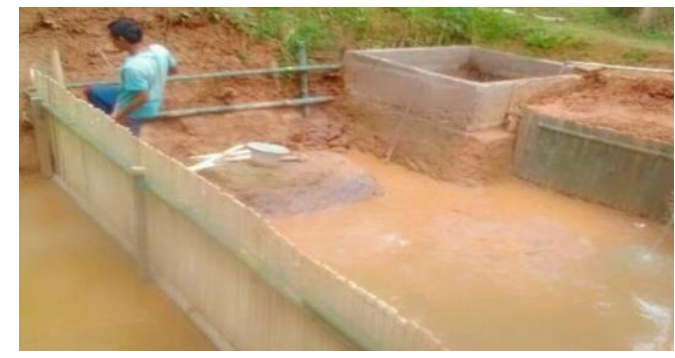

Gambar 5. Kolam Tanah

Seperti budidaya ikan lele sebelumnya pada kolam terpal dan budidaya ikan pada umumnya, budidaya ikan lele pada kolam tanah ini juga melalui tahap-tahap: persiapan kolam (tanah), persiapan bibit, pemeliharaan, dan panen. Bebeda dengan pemeliharaan pada kolam terpal yang dilakukan sebelumnya dengan full pellet, tanpa pakan alternatif, pada kolam tanah ini diberikan pakan alternatif yaitu ayam tiren. Hal ini dilakukan untuk menekan biaya produksi atau biaya operasional yaitu biaya pakan. Karena biaya pakan merupakan komponen biaya yang paling besar mencapai $70 \%$ lebih dari biayabiaya lainnya.

Setelah kolam ikan siap, selanjutnya adalah penebaran benih. Benih ditebarkan pada periode ke II ini sebanyak 5.000 ekor dengan ukuran $6-7 \mathrm{~cm}$. jumlah ini disesuiakan dengan luasnya kolam dan dengan biaya operasional.
Langkah yang tidak kalah penting lainnya dalam budidaya lele di kolam tanah yaitu melakukan pemeliharaan yang baik dan benar. Untuk pemeliharaan ikan lele di kolam tanah sangatlah mudah dan sederhana karena tidak perlu mengeluarkan biaya serta tenaga yang banyak. Pada pemeliharaan ini dilakukan pemberian pakan sebanyak dua kali sehari denga pellet dan pakan alternatif yaitu ayam tiren. Pemberian tiren ini disesuaikan dengan pasokan dari pembudidaya ayam. Apabila pasokan sedang tidak ada, diberikan full pellet selama dua kali sehari.

Setelah kurang lebih tiga bulan, ikan lele pada kolam terpal siap untuk di panen. Pada panen kedua ini menghasilkan ikan lele sebanyak $250 \mathrm{~kg}$ dengan keuntungan sebesar Rp 850.000; mitra pun tidak mengalami kesulitan dalam menjual ikan lele, karena dengan mudah menemukan pembeli atau pengepul. Pengepul sendiri yang datang ke lokasi untuk membeli seluruh ikan yang telah di panen. Setelah berhasil budidaya ikan lele pada kolam tanah ini, selanjutnya dilakukan budidaya periode selanjutnya dengan pengawasan dan pendampingan. Mitra pun diberikan pemahaman untuk senantiasa mencatat dan mendokumentasikan tahap demi tahap perkembangannya agar mudah dalam pelaksanaan monitoring dan evaluasi.

\section{Monitoring dan Evaluasi}

Monitoring dan evaluasi merupakan kegiatan yang tidak bisa dipisahkan dari proses kegiatan pengabdian masyarakat ini. Monitoring dan evaluasi dilakukan pada saat pengabdian berlangsung dan pada saat masa periode pengabdian berakhir. Pada saat pengabdian, evaluasi dilakukan dengan secara spontan dan kondisional disesuaikan dengan kebutuhan. Evaluasi ini dilakukan ketika ada masalah atau kendala dalam budidaya. Kegiatan ini sekaligus mencari solusi untuk menyelesaikan masalah atau kendala yang dihadapi. Seperti ketika terjadi kegagalan atau kematian ikan yang banyak, dilakukan 
Yayat Sujatna, Imal Istimal

Pengentasan Pengangguran Bagi Pemuda Di Desa Cigudeg Melalui Kegiatan Budidaya Ikan Lele

pengamatan dan mencari tahu penyebab kematiannya dan dicarikan solusinya.

Sementara evaluasi setelah pengabdian masyarakat berlangsung dilakukan untuk mengetahui kendala atau masalah serta persepsi khalayak sasaran tentang proses pengabdian masyarakat ini secara keseluruhan serta rencana tindak lanjut pengabdian ini. Pada evaluasi ini dilakukan dengan cara dialog antara pelaksana dengan khalayak sasaran tentang kegiatan pengabdian masyarkat ini.

Secara keseluruhan, mitra (khalayak sasaran) menilai, kegiatan ini telah memberikan manfaat yang besar bagi mitra dan berjalan dengan lancar. Mitra yang tadinya awam tentang budidaya ikan lele menjadi paham dan akan terus ditingkatkan pengetahuannya melalui budidaya ikan lele sampai dengan menghasilkan keuntungan yang diharapkan.

Sementara kendala yang dihadapi saat ini adalah bagaimana memperoleh bibit yang bagus. Meskipun ada namun tidak banyak di daerah sekitar lokasi yang menjual atau pembibitan ikan lele. Sehingga untuk mendapatkan bibit mengalami kesulitan karena selain para pembibit memproduksi secara terbatas juga banyak yang membutuhkan bibit lele yang bagus. Untuk itu diperlukan pelatihan cara pembibitan ikan lele. Kegiatan ini penting untuk membantu khalayak sasaran agar tidak tergantung pada bibit lele dari orang lain yang ketersediaannya tidak terjamin.

\section{SIMPULAN}

Berdasakan hasil pengabdian masyarakat terhadap pemuda di Kp. Ciuncal, Ds/Kec. Cigudeg, Kab. Bogor - Jawa Barat ini, dapat disimpulkan sebagai berikut:

1. Pelaksanaan pengabdian masyarakat bidang kewirausahaan dapat meningkatkan minat masyarakat dalam berwirausaha melalui potensi kearifan lokal;

2. Pelaksanaan pengabdian dapat meningkatkan pendapatan mitra (khalayak sasaran);

3. Penggunaan kolam tanah lebih baik dan berhasil dibandingkan menggunakan kolam terpal.

4. Perlu dilakukan pengabdian atau pelatihan lanjutan, seperti pembibitan dan manajemen produksi pasca panen.

\section{DAFTAR PUSTAKA}

Burhanudin (2010). Mendorong Pertumbuhan Ekonomi Melalui Peningkatan Jumlah Wirausaha: Sebuah Kerangka Penelitian. Orange Book. Departemen Agribisnis FEM IPB

Dimyati, M., dan Sari., N., K., (2015) Iptek

Bagi Masyarakat (IbM) Wirausaha Baru

Pemuda Karang Taruna Di Desa

Sanenrejo Kecamatan Tempurejo Kab.

Jember. Jurnal Pengabdian Masyarakat

Ipteks.

jurnal.unmuhjember.ac.id/index.../PEN

GABDIAN_IPTEKS/.../181

Konadi, W., Irawan, D., (2012). Tinjauan Konseptual Kewirausahaan Dalam Bisnis Pembentukan Wirausaha Baru Untuk Mengatasi Pengangguran. Jurnal Ekonomika Universitas Almuslim Bireuen-Aceh, III, (5), 62-75

Muhammad, W., N. dan Andriyanto, S., (2013). Manajemen Budidaya Ikan Lele Dumbo (Clarias gariepinus) di Kampung Lele, Kabupaten Boyolali, Jawa Tengah. Media Akuakultur,8, (1), 63-71 
Yayat Sujatna, Imal Istimal

Pengentasan Pengangguran Bagi Pemuda Di Desa Cigudeg Melalui Kegiatan Budidaya Ikan Lele

Kemendikbud, (2013), Modul Pembelajaran

Kewirausahaan. Sumber:

https://philarchive.org/archive/FUGAC

$\mathrm{N}$ (diakses pada Februari 2018) 